\title{
Bamboo Mat as a Temporary Reinforced Soil Retaining Wall in a Railway Bed
}

\author{
Nur Alfian Sasmayaputra, Agus Darmawan Adi, Fikri Faris \\ Department of Civil and Environment Engineering, \\ Faculty of Engineering, Universitas Gadjah Mada \\ Indonesia \\ alfiansasmayaputra@gmail.com,adadhi2@yahoo.com, \\ fikri.faris.ugm@gmail.com
}

\begin{abstract}
One of work methods in increasing the double track lane in Java island is application of geosynthetic MSE-wall to retain new railway bed beside the existing rail track. When geosynthetic applied as a temporary reinforcement, it would be ineffective due to some considerations such as the economic aspect, because the geosynthetic function as MSE-wall will disappear if the elevation of the existing railway is increased as high as the new railway. Bamboo mats can principally be applied to replace geosytethic as temporary MSE-wall. Its more cheaper and biologically degradable feature is beneficial when used as a temporary MSE-wall. To design the structure of MSE-wall, the pullout resistance value shall be obtained by a test. This research aims to inform that bamboo mats as an organic local craft are feasible to be used as a slope temporary reinforcement material. The pullout resistance test refers to SNI 8128:2016. The pullout resistance test shows that $\mathrm{Ci}$ value of the bamboo mat in the heap of railway bed is 0.417 . As the sample of numeric simulation, this temporary bamboo mat MSE-wall is analyzed using Geo5 software. The numeric simulation on bamboo mat MSE-wall with $2.2 \mathrm{~m}$ high slope and the load of railway bed construction plus the train shows that they are safe from both internal and external collapses. The lowest safety factor is $\mathbf{1 . 5 3}$ with the potential of collapse due to the global slope stability. When applied as slope reinforcement, the plait size available in the market should be considered.
\end{abstract}

\section{Keywords - Bamboo mat, pull out test, temporary MSE wall}

\section{INTRODUCTION}

The reinforced soil structure for relatively straight retaining wall with surface inclination of $70^{\circ}$ to $90^{\circ}$ is commonly called Mechanically Stabilized Earth, (MSE) -wall. MSE-wall is one of slope reinforcement constructions using geosynthetic as the main component. The application of MSE-wall in Indonesia, particularly in Java, can be seen in the development of double track of Purwokerto-Kroya. It is applied as a temporary reinforcement in the inner side of the new heap beside the operating railway. Upon the completion of the new track, the trains are moved to that track and the old one can be elevated according to the plan without disturbing the train operation. Figure 1 presents geosynthetic as a temporary reinforced retaining wall in the railway bed.

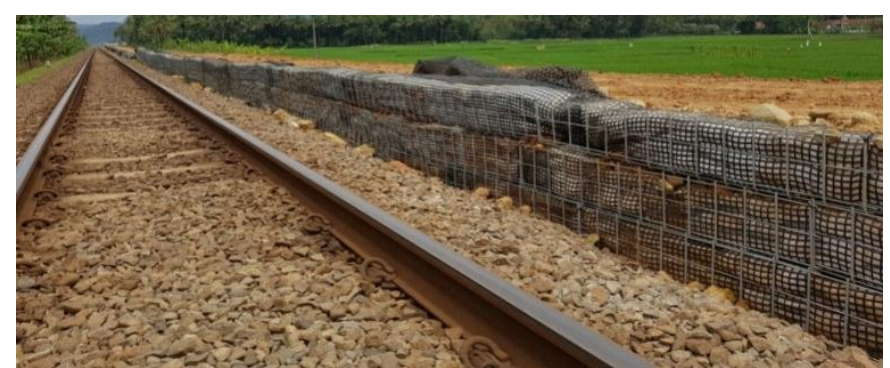

Fig. 1. MSE-Wall in the Railway Bed Construction

Geosynthetic is commonly used as short and long term reinforcement. However when applied as a temporary reinforcement, it would be ineffective due to some considerations such as the economic aspect. Bamboo mat is physically a sheet and can be used to replace the geosynthetic. To find out if it can be utilized as a temporary reinforced soil retaining wall, it should be tested regarding its mechanical nature, similar to the geosynthetic, through a laboratory testing.

This research aims to test the potential of bamboo mat as a temporary reinforced retaining wall in railway bed. The pullout resistance value is one of the important parameter inputs in the analysis of MSE-wall modeling. Koutsourais et al (1998) state that pullout test can simulate the MSE-wall actual collapse. This research also tests the pullout resistance of bamboo mat buried under the heap soil of railway bed.

\section{LITERATURE REVIEW}

MSE-wall structure is basically a soil reinforcement to help retaining against the working lateral force. The earth mass in the reinforced zone is retained by reinforcement act from the geosynthetic sheet of which the outer ends are bent. Reinforced landfill is also a retaining material against the load and media burdening the retaining wall system. When the wall undergoes deformation, the lateral pressure underground reaches the passive zone through the friction between the soil and the geosynthetic (Hardiyatmo, 2013).

A slip surface on a vertical wall with soil reinforced by some elastic bars is usually considered coinciding with Rankine slip surface, meaning that collapse occurs in a surface of $\left(45^{\circ}+\varphi / 2\right)$ degree against horizontal surface (Bell et al., 1975 in Hardiyatmo, 2013). Therefore, regarding geosynthetic- 
reinforced soil, active earth pressure coefficient $\left(K_{a}\right)$ is used in lateral soil calculation. In its function as reinforcement bars, geosynthetic provides pullout resistance as shown in Figure 2. In the reinforced soil, the earth pressure transfer mechanism comes from the friction between the earth and the reinforcement. With this friction, the earth transfers the pressure of forces working against it to the reinforcement bars.

Uniformly distributed load

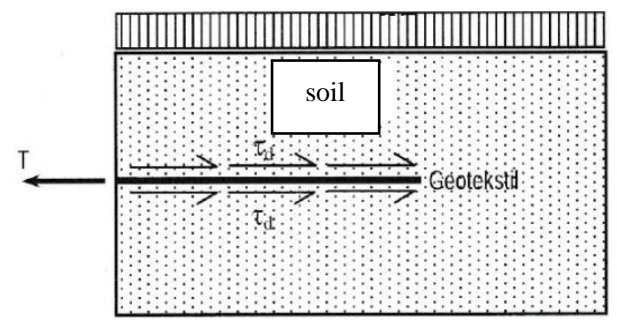

Fig. 2. Pullout Test And Forces Working In Geosynthetic Bars (Gourc, 1982 in Hardiyatmo, 2013).

The pullout total resistance in geotextile is the result of friction resistance contribution. The friction resistance is evaluated using Mohr-Coulomb criteria, depending on the type of the soil (the degree of earth friction and earth interface), the degree of interface friction, the interface adhesion, the buried area, and the confining pressure (Koutsourais et al., 1998). The interaction coefficient or $C_{I}$ is important as a part of design parameter (Cowell et al., 1993; Koutsourais et al., 1998; and Tatlisoz et al., 1998)., $C_{I}$ can be defined as a ratio of interface strength between the reinforced soil and the soil shear strength.

Some types of bamboos that can be used as plaits are apus or ali (Gigantochloa apus), legi or andong (Gigantochloa verticillata) and wulung or atter (Gigantochloa atter). The bamboo mats or gedheg are made of bamboos thinly sliced and woven. The bamboo slats are $2-3 \mathrm{~cm}$ wide. The slicing of these slats is adjusted to the diameter or circumference as well as the bamboo's inner and outer thickness.

The traditional technology has put bamboo mat as a material to reinforce soil such as in soft sub base soil, pond reclamation and so on. The research on bamboo mats as the sub base soil reinforcement has been conducted previously by Suwartanti (2015). The research tells to what extent bamboo can be used as a material for reinforcing the stability of foundation soil.

Other research on the effects of bamboo mats regarding its supporting capacity and the decline of shallow foundation in cohesive soil has also been conducted by Surjandari (2007). Adi (2004) has carried out a study of the influence bamboo mat insert in the sandy soil regarding soil supporting capacity. The result of the study shows that the application of bamboo mats can increase the subset soil supporting capacity.

Hedge (2015) conducts a research on the soft sub base soil reinforcement using bamboos. Bamboos as the reinforcement is combined with bamboo cell and bamboo mats. The strength of soil supporting capacity with reinforcement from the combination is then compared with the reinforcement from the geocell and geogrid combination. The result shows that the ultimate capacity of the bamboo cell and bamboo mats combination is higher by 1.3 times than the other one.
In interpreting the result of pullout test, it is assumed that the apparent shear stress $\left(\tau_{a p}\right)$ of the geosynthetic can be calculated using this formula:

$$
\tau_{\text {ap }}=\frac{T_{\text {ult }}}{2 \cdot A}
$$

$T_{\text {ult }} \quad$ : ultimate shear stress $(\mathrm{kN})$

$A \quad$ : area of the buried geosynthetic $\left(\mathrm{m}^{2}\right)$

Using Mohr-Coulomb criteria, here is the relation between apparent pullout resistance and confining pressure to define the parameter of the interface shear stress for the soil reinforced by reinforcement material mobilized by soil-geosynthetic interface angle of friction $(\delta)$ and adhesion $\left(c_{a p}\right)$ :

$$
\tau_{a p}=c_{a p}+\sigma_{n} \cdot \tan \delta
$$

with:

$\tau_{a p} \quad:$ interface shear strength between the soil and the geosynthetic $\left(\mathrm{kN} / \mathrm{m}^{2}\right)$

$\sigma_{n} \quad:$ effective normal stress on the shear face $\left(\mathrm{kN} / \mathrm{m}^{2}\right)$

$c_{a p} \quad:$ geosynthetic adhesion against soil $\left(\mathrm{kN} / \mathrm{m}^{2}\right)$

: soil interface and geosynthetic angle of friction $\left(^{\circ}\right)$

Parameter $C_{i}$ is used to calculate the length of attachment of the reinforcement needed in the critical failure plane, according to (Tatlisoz et al, 1988) coefficient $C_{I}$ in the soil can be calculated using this equation:

$$
C_{i}=\frac{\varepsilon_{\mathrm{a}}+\sigma_{n} \tan \varepsilon}{c+\sigma_{n} \tan \varphi}
$$

$C_{i} \quad$ : coefficient of interface shear

$c_{a} \quad:$ adhesion of soil-geosynthetic $\left(\mathrm{kN} / \mathrm{m}^{2}\right)$

c : cohesion of undrained soil $\left(\mathrm{kN} / \mathrm{m}^{2}\right)$

: interface soil-geosynthetic surface angle of friction

$\left({ }^{\circ}\right) \quad$ : soil internal angle of friction $\left(^{\circ}\right)$

\section{METHOD}

In this research testing is conducted in the Laboratory of Soil Mechanics, Civil and Environment Engineering, Gadjah Mada University. The primary testing includes a geosynthetic pullout resistance test referring to the SNI (the Indonesian National Standard) 8128:2016 regarding geosynthetic pullout testing. Figure 3 displays the pullout resistance testing equipment used for this research.

The pullout resistance test is conducted 9 times with different stress variation. The calculation of stress application is based on the field condition regarding the load of the train and the railway bed construction. The speed of bamboo mat pullout is set at $5 \mathrm{~mm} /$ minutes. The total length of displacement of bamboo mats is limited to $50 \mathrm{~mm}$.

The secondary test is concerned with soil property index. The object soil is taken from the fill in the heap structure. This test includes the distribution of grain size referring to the standard of ASTM D 422. The test of consistency index and plasticity refers to ASTM D 4318 standard; the specific gravity to ASTM D 854 standard; the compaction to ASTM D 698 
standard; and the soil shear strength was tested by UU triaxial test.

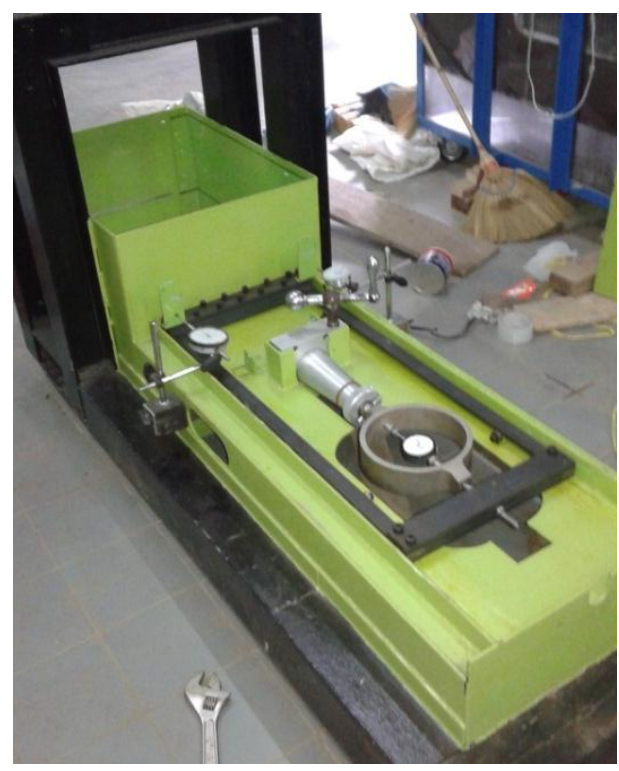

Fig. 3. Pullout Resistance Testing Box

Proctor Compaction test is used as the base of the optimum compaction in the pullout resistance box. As the object of pullout resistance test, a bamboo mat is cut into rectangular shape with the size of $\pm 610 \times 305 \mathrm{~mm}$. Figure 4 presents the picture of a bamboo mat in the adjusted size. Bamboo mat used as the object of this test have these following criteria:

1. They are obtained from the craftsmen around the research area, i.e. Purwokerto and Kroya (Central Java).

2. They are made of the inner part of apus bamboo (Gigantochloa apus).

3. The plait pattern is bilik and each bamboo slat is around $20 \mathrm{~mm}-35 \mathrm{~mm}$ wide.

4. Their thickness is around $1.5 \mathrm{~mm}-2.5 \mathrm{~mm}$.

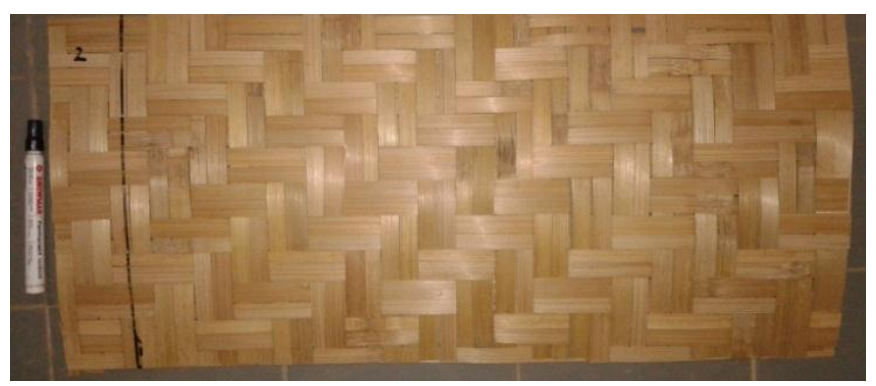

Fig. 4. Bamboo mat as the object of the test

The pullout resistance test is conducted after the plaits have been soaked for 24 hours. Prior to the test, while they are wet, they are drained for \pm 2 minutes to anticipate the increase of water content in the soil directly in touch with the plait. The result of this test is then analyzed regarding its interface shear strength. Geo5 software is used to analyze the simulation of bamboo mat as an MSE-wall.

\section{RESULT AND DISCUSSION}

The test result upon the soil heap classification in a railway bed and the soil physical nature is presented in Table I. According to the USCS (the unified soil classification system) it is categorized under $M H$, inorganic silt with granular sand and clay with high plasticity. The evaluation on the soil shear strength is conducted using a triaxial test. The sample of the object is adjusted to the value of $O M C$ and $M D D$ of the proctor testing. From test result, it is found out that the cohesion value of the heap soil in the railway bed is $42.749 \mathrm{kN} / \mathrm{m}^{2}$ and the angle of internal friction is $6.65^{\circ}$.

TABLE I. RESUlt OF LABORATORY TEST OF THE HEAP SOIL IN THE RAILWAY BED

\begin{tabular}{|c|l|c|c|c|}
\hline No & \multicolumn{1}{|c|}{ Parameter } & Symbol & Value & Unit \\
\hline 1 & Moist unit weight & $\gamma$ & 18.023 & $\mathrm{kN} / \mathrm{m}^{3}$ \\
\hline 2 & Specific Gravity & $G s$ & 2.694 & - \\
\hline 3 & Liquid Limit & $L L$ & 53.5 & $\%$ \\
\hline 4 & Plastic Limit & $P L$ & 34 & $\%$ \\
\hline 5 & Plasticity Index & $P I$ & 19.3 & $\%$ \\
\hline 6 & $\%$ sand & & 46.290 & $\%$ \\
\hline 7 & $\%$ fine grain & $O M C$ & 29.2 & $\%$ \\
\hline 8 & Optimum water content & $M D D$ & 13.95 & $\mathrm{kN} / \mathrm{m}^{3}$ \\
\hline 9 & Maximum dry density & $M H$ & & \\
\hline 10 & USCS Classification & $c$ & 42.749 & $\mathrm{kN} / \mathrm{m}^{2}$ \\
\hline 11 & Cohesion & $\varphi$ & 6.65 & $\circ$ \\
\hline 12 & Angle of Internal & & & \\
\hline
\end{tabular}

During the pullout resistance test, the bamboo mats are laid between the layers of the optimally compacted heap soil of the railway bed. After it is compacted, the box of pullout resistance is sets to normal stresses as prescribed. Normal stress occurs naturally due to the soil weight and the load of the trains and railway structure. For this research, stresses applied in the testing are among others: $78.9 \mathrm{kPa} ; 92,8 \mathrm{kPa} ; 96.6 \mathrm{kPa} ; 154.3$ $\mathrm{kPa} ; 154.4 \mathrm{kPa} ; 156 \mathrm{kPa} ; 227.8 \mathrm{kPa} ; 228.7 \mathrm{kPa}$; and $229.6 \mathrm{kPa}$. Table II and Figure 5 inform the value of pullout force and pullout resistance resulting from the test.

TABLE II. RECAPITULATION OF CALCULATION UPON THE PULlOUT RESISTANCE OF BAMBOO MATS IN THE HEAP SOIL OF THE RAILWAY BED

\begin{tabular}{|c|c|c|c|c|}
\hline \multirow{3}{*}{ Sample No. } & \multirow{3}{*}{$\begin{array}{c}\text { Normal } \\
\text { Stress } \\
(\mathbf{k P a})\end{array}$} & $\begin{array}{c}\text { Maximum } \\
\text { Pullout } \\
\text { Force }(\mathbf{k N}) \\
\end{array}$ & $\begin{array}{c}\text { Buried } \\
\text { Surface } \\
\left(\mathbf{m}^{2}\right)\end{array}$ & $\begin{array}{c}\text { Pullout } \\
\text { Resistance } \\
(\mathbf{k P a}) \\
\end{array}$ \\
\hline & & \multirow[b]{2}{*}{ (a) } & \multirow[b]{2}{*}{ (b) } & (c) \\
\hline & & & & $(\mathbf{c})=\frac{(a)}{2 x(b)}$ \\
\hline 5 & 78.971 & 7.210 & 0.186 & 19.378 \\
\hline 8 & 92.875 & 7.661 & 0.176 & 21.654 \\
\hline 7 & 96.600 & 8.012 & 0.183 & 21.890 \\
\hline 3 & 154.351 & 9.063 & 0.186 & 24.358 \\
\hline 2 & 154.423 & 9.138 & 0.186 & 24.479 \\
\hline 10 & 156.091 & 9.263 & 0.186 & 24.896 \\
\hline 4 & 227.829 & 10.215 & 0.186 & 27.453 \\
\hline 6 & 228.729 & 10.515 & 0.186 & 28.260 \\
\hline 9 & 229.622 & 10.891 & 0.183 & 29.757 \\
\hline
\end{tabular}




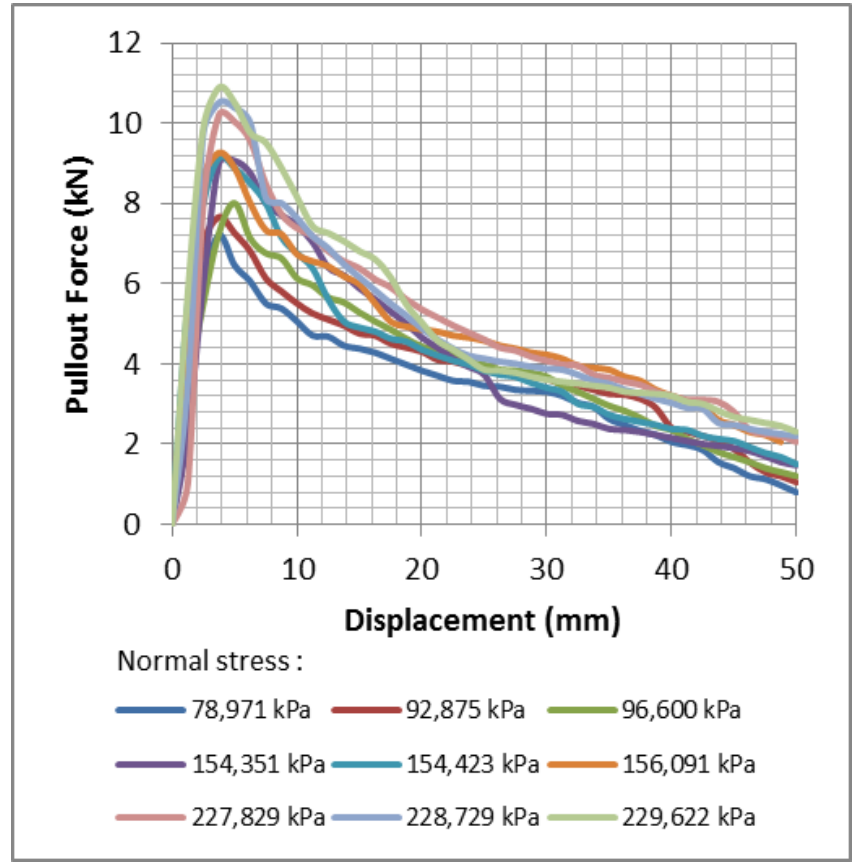

Fig. 5. Chart on Relation of Pullout Force and Displacement

The interface shear strength/ interaction shear strength between the soil and different materials can be calculated based in Mohr-Coulomb criteria consisting of attachment component and the angle of shear. From the chart above, which is about pullout resistance in clay, it can be seen that the interface shear strength is more dominant than the adhesion or attachment of bamboo mats and soil. It is proved by the test result presenting displacement up to $50 \mathrm{~mm}$ before reaching out the residual zone.

The residual shear strength is influenced by the value of the angle of friction and the normal stress. The shear strength of the clay consists of a cohesion and an angle of internal friction. Usually, the cohesion value is high, and the angle of friction value is low. The occurring collapse pattern of the pullout resistance will decrease faster because the attachment strength diminishes and the angle of interface shear is small.

The value of normal stress applied in the test of pullout resistance will increase the effort of pullout force. The bigger the normal stress is, the bigger the effort will be to pullout the bamboo squeezed under the soil. The pullout force needed to pull the reinforcement sheet out of an area is called pullout resistance. When bamboo mats are used as soil reinforcement material, the pullout resistance applies on the top and bottom sides.

According to Elias (2001), pullout resistance is caused by the contribution of stress transfer mechanism on the reinforcement area. The form of mechanism can be frictional resistance and passive bearing resistance. Frictional resistance is caused by a friction between soil and geotextile or geomembrant. Meanwhile, passive bearing resistance comes out of the soil squeezed in the transverse area of the direction of pullout force occurring upon the geogrid and geonet. Based on the visual observation, and by considering the shape and the texture of bamboo mats, the pullout resistance will be influenced by frictional resistance value which can be analyzed with Mohr-Coulomb shear strength criteria.

In Mohr-Coulomb shear strength criteria, the relation between the maximum pullout resistance with the applied normal stress is used to determine the interface shear strength. In this condition, the strength is the peak or maximum shear strength before and/or when a material collapse occurs. Figure 6 shows the chart regarding the relation of normal stress and maximum pullout resistance of each test.

Using Mohr-Coulomb shear strength criteria, the interface shear strength or apparent shear strength of the bamboo mat soil can be seen in a linear regression line in figure 6 . Therefore, the interface shear strength of bamboo mat in the heap soil of the railway bed got adhesion value $=16.071 \mathrm{kPA}$ and angle of interface friction $(\delta)=3.125^{\circ}$.

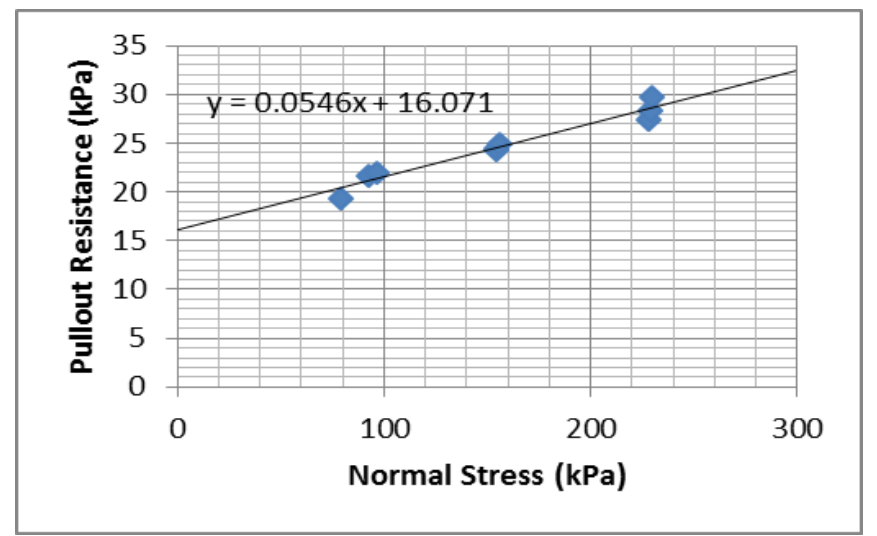

Fig. 6. Chart of Relation between Normal Stress and Pullout Resistance

The value of apparent shear strength of the bamboo matsoil is almost the same as the interface shear strength of woven geosynthetic in the clay soil defined through the laboratory pullout testing conducted by Mohiuddin (2001) and the laboratory direct shear testing conducted by Rifa'I (2009). It is in accord with this research; that within the apparent shear strength possessed by bamboo mat - soil, the interface shear is derived from the adhesion value or attachment and the internal skin friction. However the value of apparent shear strength or interface shear strength is strongly influenced by the soil material's shear strength.

One of the parameter input necessary in the design of soil reinforcement using geosynthetic is the value of coefficient of interaction $\left(C_{i}\right)$ between the geosynthetic and the soil. It is used to calculate the length of binding of the reinforcement needed in the critical collapse zone. Its value is the ratio between the shear strength of the bamboo mats-soil and the shear strength of the soil. By using equation 3 the $C_{I}$ value from the interface between soil and bambbo mat is 0,417 .

In the research conducted by Mohiuddin (2001), if the value of interaction coefficient is less than 0.5 , normally it indicates a weak binding between the soil and the reinforcement sheet or that there is some damage in the geosynthetic specimen. Usually, the value of $C_{I}$ is 0.5 or more. The pullout resistance test upon the heap soil of the railway bed dominated by silt-clay reveals that the value of interaction coefficient is less than 0.5 . This ineffective interaction may 
occur due to mechanic behavior of the reinforced soil or the break of the testing object. However the second factor does not likely to happen since the collapse between the soil and the bamboo mats occurred when the pullout force value is lower than the bamboo mat pullout strength. Other possibility is the slip of the horizontal and vertical reinforcement bars within the bamboo mat so that it may decrease the pullout strength happening to the interface area.

An example of numeric calculation of the use of bamboo mat as a geosynthetic replacer can be attained using Geo5 Software. In the case of heap of railway bed it is considered that the height is $2.2 \mathrm{~m}$ in the design. That number is determined because bamboo mat is a non-homogeneous material with various quality, biologically degradable and is only $5 \mathrm{~m}$ long at the most. Based on the calculation, the need of reinforcement bars in the active and passive zones is limited to $3 \mathrm{~m}$ maximum and the space between them is $30 \mathrm{~cm}$. Figure 7 demonstrates geometrical design of bamboo mat MSE-wall in the heap of railway be.

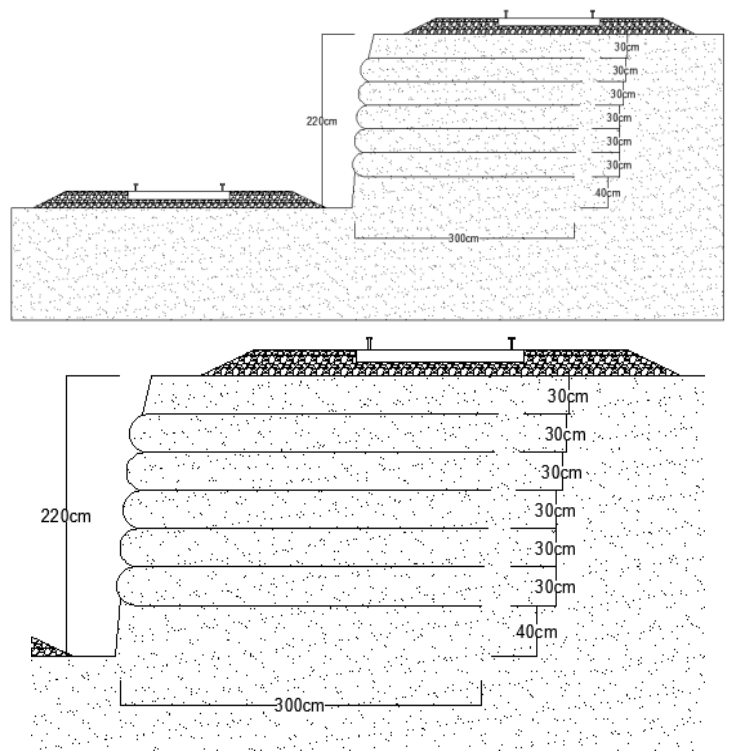

Fig. 7. The cut of bamboo mat MSE-wall design

In several parameter inputs regarding the types of reinforcement such as Short term char. strength $\left(T_{u l t}\right)$, long term design strength $\left(R_{t}\right)$, and coefficient of direct slip along reinforcement $\left(C_{d s}\right)$, the data cannot be collected validly through a short term char. laboratory. The value of the strength is then obtained through a bamboo pullout strength test conducted by the researchers (unpublished) with $T_{u l t}=$ $70 \mathrm{kN} / \mathrm{m}$ '. Whereas for long term design strength $40 \mathrm{kN} / \mathrm{m}$ ' is applied.

In this research, the interface shear strength is only obtained from pullout resistance test. Koutsourais et al (1998) compare the test result of pullout and direct shear against cohesion soil. The study concludes that that pullout test provides a value of $13-17 \%$ higher than it is of soil interaction in direct shear. Therefore if $C_{I}=0.417, C_{d s}=0.346$ can be applied.

Meanwhile, the load input refers to the research of Susanto (2015) which studies railway class I with ballast thickness of
$73.1 \mathrm{~cm}$. It concludes that the load rising from the train and the railway structure is $65.8 \mathrm{kN} / \mathrm{m}^{2}$. Table III presents the values of parameter input used as the basis of MSE-wall analysis in Geo5.

TABLE III. INPUT OF $M S E$-WALL GEO5

\begin{tabular}{|l|c|}
\hline \multicolumn{1}{|c|}{ Parameter } & Value \\
\hline Geometry & $2.5 \mathrm{~m}$ \\
\hline Embankment height & $0.05 \mathrm{~m}$ \\
\hline Embankment length \\
\hline Type of Reinforcement & $70 \mathrm{kN} / \mathrm{m}^{\prime}$ \\
\hline Short term char. Strength $\left(T_{u l t}\right)$ & $40 \mathrm{kN} / \mathrm{m}^{\prime}$ \\
\hline Long term design strength $\left(R_{t}\right)$ & 0.346 \\
\hline $\begin{array}{l}\text { Coefficient of direct slip along } \\
\text { reinforcement }\left(C_{d s}\right)\end{array}$ & 0.417 \\
\hline $\begin{array}{l}\text { Coefficient of interaction of soil and } \\
\text { georeinforcement }\left(C_{i}\right)\end{array}$ & \\
\hline Reinforcement & 6 \\
\hline Number of reinforcement & $0.5 \mathrm{~m}$ \\
\hline Height of first reinforcement $(h)$ & $0.5 \mathrm{~m}$ \\
\hline Spacing of reinforcements $\left(h_{r}\right)$ & $3 \mathrm{~m}$ \\
\hline Reinforcement length $(l)$ & $18.023 \mathrm{kN} / \mathrm{m}^{3}$ \\
\hline Soil & $6.65^{\circ}$ \\
\hline Unit weight $(\gamma)$ & $42.749 \mathrm{kN} / \mathrm{m}^{2}$ \\
\hline Internal skin friction $\left(\varphi_{e f}\right)$ & $3.125^{\circ}$ \\
\hline Cohesion of soil $\left(c_{e f}\right)$ & $23.760 \mathrm{kN} / \mathrm{m}^{3}$ \\
\hline Angel of friction struc-soil $(\delta)$ & Surface \\
\hline Saturated unit weight $\left(\gamma_{\text {sat }}\right)$ & permanent \\
\hline Surcharge & $65.8 \mathrm{kN} / \mathrm{m}^{2}$ \\
\hline Type & \\
\hline Type of action & \\
\hline Magnitude & \\
\hline
\end{tabular}

The analysis infers that the temporary reinforced retaining wall made of bamboo mat in the railway bed as high as $2.2 \mathrm{~m}$ (Figure 7) is safe from collapse. In details, table 4 shows the recapitulation of safety factors from Geo5 analysis. The lowest safety factor can be achieved when slope stability global has SF of 1.54. Stability global is one of correction calculations on the slope where MSE-wall structure block might collapse. Figure 8 shows the visualization of slip surface in the MSEwall structure that is likely to collapse according to Geo5 analysis.

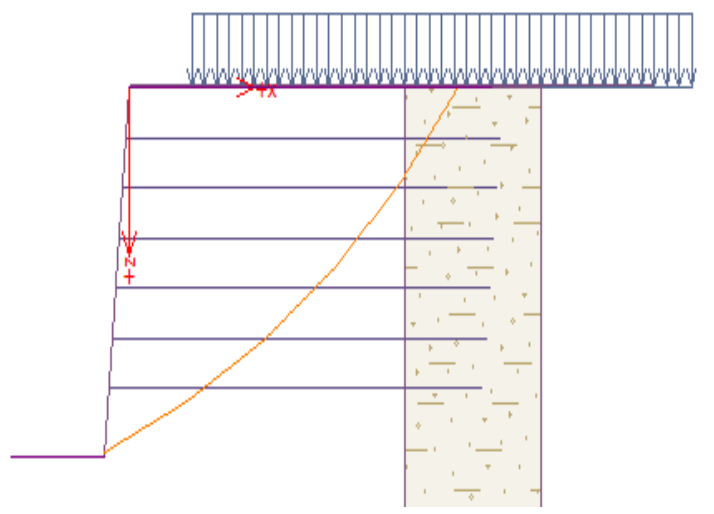

Fig. 8. Critical Potential Slip Surface in Slope Reinforcement of the Railway Bed Using Bamboo mat. 
TABLE IV. RECAPITULATION OF THE GEO5 ANALYSIS ON SAFETY FACTORS

\begin{tabular}{|l|c|}
\hline \multicolumn{1}{|c|}{ Analysis } & $\begin{array}{c}\text { Safety } \\
\text { Factor }\end{array}$ \\
\hline Verification & 1000 \\
\hline Overtuning & 1000 \\
\hline Slip & 3.39 \\
\hline Bearing capacity & 1000 \\
\hline V-Bearing capacity & $9.3 \mathrm{~mm}$ \\
\hline H-Bearing capacity & 1000 \\
\hline Foundation settlement & 1000 \\
\hline Slip on Reinforcement (reinforced no 1) & 317.87 \\
\hline Internal stability & 1.54 \\
\hline Check tensile strength (reinforced no 1) & 1.53 \\
\hline Check pullout resistance (reinforced no 1) & \\
\hline Global stability & \\
\hline Slope stability check (Bishop) & \\
\hline Slope stability & \\
\hline Slope stability verification (Bishop) & \\
\hline
\end{tabular}

\section{CONCLUSION}

According to USCS system, the heap soil in the railway bed used in the field and for the pullout test resistance for this research belongs to $M H$, i.e. inorganic silt soil with grainy sand and clay with high plasticity. Regarding the soil shear strength value from the triaxial testing in $O M C$ and $M D D$ condition, it is concluded that the cohesion is $42.749 \mathrm{kN} / \mathrm{m}^{2}$ and the angle of internal friction is $6.65^{\circ}$.

The pullout resistance test is conducted 9 times with different normal stress application. The value of maximum pullout force in each test is divided by the area of both buried sides and will result in the value of maximum pullout resistance. The value of maximum pullout resistance and the application of normal stress are plotted in the relation chart and it creates a linear line on the equation of interface shear strength. The pullout resistance test upon bamboo mat under the railway bed heap soil points out that the adhesion value is $16.071 \mathrm{kPA}$ and the angle of interface shear $(\delta)=3.125^{\circ}$

Interaction coefficient as an important parameter in the MSE wall planning is acquired from the ratio of interface shear strength and soil shear strength. According to result of the test of bamboo pullout resistance in the heap soil in the railway bed, $C_{I}=0.417 . C_{I} \leq 0,5$ indicates weak binding between the soil and its reinforcement. It happens to the bamboo mat under the heap soil of railway bed because of the collapse upon the interaction of shear strength and the soil.

The numeric modeling on MSE-wall using bamboo mat on the railway bed with the slope of $2.2 \mathrm{~m}$ high and railway construction load of $65.8 \mathrm{kN} / \mathrm{m}^{2}$ indicates that it is safe from collapsing with the lowest SF of 1.53. The design of MSE-wall using bamboo mat should consider the availability of it in the market (they come with the size of ax $m$ the biggest). Therefore, it is recommended that the usage of bamboo mat shall be limited by the length of reinforcement bars buried in the active and passive zone of maximum $3 \mathrm{~m}$.

\section{REFERENCES}

[1] Adi. A. D.. 2004. Pengaruh Sisinan Anyaman Bambu dalam Tanah Pasir terhadap Kuat Dukung Tanah.Forum Teknik Sipil UGM, Volume 28.

[2] ASTM, 2003, Annual Book of ASTM Standards, Section 4, Vol. 04.08, West Conshohocken.

[3] Cowell, M. \& Sprague, C., 1993. Comparison of Pullout Performance of Geogrids and Geotextiles. Geosyntethic, pp. 579-592.

[4] Elias, V., Christopher, B. R. \& Berg, R. R., 2001. Mechanically stabilized earth walls and reinforced soil slopes, Washington DC: FHWA.

[5] Hardiyatmo, H. C., 2013. Geosintetik untuk rekayasa jalan raya perancangan dan aplikasi. 2nd ed. Yogyakarta: UGM PRESS.

[6] Hegde, A. \& Sitharam, T., 2015. Use of Bamboo in SoftGround Engineering and Its Performance Comparison with Geosynthetics: Experimental Studies. Journal of Materials in Civil Engineering.

[7] Koutsourais, M., Sandri, D. \& Swan, R., 1998. Soil Interaction Characteristics of Geotextiles and Geogrids. Geosynthetics '98, pp. 739-744.

[8] Mohiuddin, A., 2003. Analysis of Laboratory and Field Pullout Tests of Geosynhthetics In Clayey Soils, Osmania: Osmania University.

[9] Rifa'i, A., 2009. Behavior of Soil-Geotextile Interaction on the Shear Strength Parameters. Dinamika Teknik Sipil, Januari, Volume 9, No 1, pp. 92 - 100.

[10] SNI, 2016, Metode uji pengukuran tahanan cabut geosintetik dalam tanah (ASTM D 6706 - 01 (2007), IDT, SNI 8128:2016. Jakarta: Badan Standardisasi Nasional.

[11] Surjandari, N. S., 2007. Pengaruh Anyaman Bambu Terhadap Daya Dukung Dan Penurunan Pondasi Dangkal Pada Tanah Kohesif. Jurnal Media Teknik Sipil, Januari .Volume 49.

[12] Susanto, N. B., 2015. Analisis Distribusi Beban Kereta Api Pada Konstruksi Timbunan Jalur Kereta Api, Yogyakarta: Universitas Gadjah Mada.

[13] Suwartanti, 2005. Perilaku Mekanik Tarik Bambu dan Potensi Aplikasinya Sebagai Perkuatan Tanah Pada Timbunan. Jurnal INERSA, Maret, Volume I No.1, pp. 39-47.

[14] Tatlisoz, N., Edil, T. \& Benson, C., 1998. Interaction Between Reinforcing Geosynthetics and Soil-Tire Chip Mixtures. Journal of Geotechnical and Geoenvironmental Engineering, pp. 1109-1119. 